\title{
Detection of 'Candidatus Liberibacter asiaticus' in Diaphorina citri and Its Importance in the Management of Citrus Huanglongbing in Florida
}

\author{
K. L. Manjunath, S. E. Halbert, C. Ramadugu, S. Webb, and R. F. Lee
}

First and fifth authors: U.S. Department of Agriculture-Agricultural Research Service (USDA-ARS), National Clonal Germplasm Repository for Citrus and Dates, Riverside, CA 92507; second author: Florida Department of Agriculture and Consumer Services, Division of Plant Industry, Gainesville, FL; third author: Department of Botany and Plant Sciences, University of California, Riverside 92521; and fourth author: University of Florida, Entomology and Nematology Department, Gainesville 32611.

Accepted for publication 26 November 2007.

\begin{abstract}
Manjunath, K. L., Halbert, S. E., Ramadugu, C., Webb, S., and Lee, R. F. 2008. Detection of 'Candidatus Liberibacter asiaticus' in Diaphorina citri and its importance in the management of citrus huanglongbing in Florida. Phytopathology 98:387-396.

Citrus huanglongbing (HLB or citrus greening), is a highly destructive disease that has been spreading in both Florida and Brazil. Its psyllid vector, Diaphorina citri Kuwayama, has spread to Texas and Mexico, thus threatening the future of citrus production elsewhere in mainland North America. Even though sensitive diagnostic methods have been developed for detection of the causal organisms, Candidatus Liberibacter spp., the pathogen cannot be detected consistently in plants until symp-

toms develop, presumably because of low titer and uneven distribution of the causal bacteria in nonsymptomatic tissues. In the present study, TaqMan based real-time quantitative polymerase chain reaction methodology was developed for detection of ' $C a$. L. asiaticus' in D. citri. Over 1,200 samples of psyllid adults and nymphs, collected from various locations in Florida, from visually healthy and HLB symptomatic trees at different times of the year were analyzed to monitor the incidence and spread of HLB. The results showed that spread of ' $\mathrm{Ca}$. L. asiaticus' in an area may be detected one to several years before the development of HLB symptoms in plants. The study suggests that discount garden centers and retail nurseries may have played a significant role in the widespread distribution of psyllids and plants carrying HLB pathogens in Florida.
\end{abstract}

Citrus huanglongbing (HLB or citrus greening), a highly destructive disease of citrus, has been endemic in many Asian and some African citrus growing areas for several decades $(4,10,18)$. The disease has not been managed effectively in any of these regions and has been responsible for the destruction of several citrus industries in Asia and Africa (3). HLB was detected recently in both Sao Paulo, Brazil $(8,47)$, and Florida, United States (17), causing serious concern, since the two countries produce about one-third of the world's citrus (1). The disease is caused by a fastidious phloem-limited bacterium that has not yet been cultured. Presently three species of the causal organism are recognized: 'Candidatus Liberibacter asiaticus', ' $\mathrm{Ca}$. L. africanus', and 'Ca. L. americanus'. Two psyllids, Diaphorina citri Kuwayama (7) and Trioza erytreae (del Guercio) (37), vector the disease. The former is the principal vector in Asia, Brazil, and Florida, while the latter transmits the disease in Africa.

D. citri has been present in Brazil for over 60 years $(4,33)$ and in Florida since 1998 (19), but HLB appeared almost simultaneously in both these places. The psyllid was reported from Texas in 2001 (12) and from several countries in the Caribbean basin (21). Even though the psyllid was officially reported from Mexico in 2004 (9), USDA intercepts in the United States suggest its presence there at least since 1996 (21).

HLB is a difficult disease to manage due to the nonspecific nature of disease symptoms, prolonged latency of the disease in field trees, probable irregular distribution of the pathogen in trees,

Corresponding author: R. Lee; E-mail address: rivrl@ars-grin.gov

doi:10.1094/PHYTO-98-4-0387

This article is in the public domain and not copyrightable. It may be freely reprinted with customary crediting of the source. The American Phytopathological Society, 2008. effect of environment (especially temperature) on symptom expression and possibly on bacterial multiplication, probable variations in tolerance to the bacterium in both the plant host and the vectors, and the fastidious nature of the bacterium. Even the most sensitive diagnostic tests available today are not adequate to certify a vector compromised tree as HLB-free. The tests can be treated only as confirmatory without much diagnostic value. A reliable plant-based diagnostic test probably would have to be based on a host systemic response specific to HLB, which presently is unknown.

Visual symptoms and biological indexing have been the historical means of diagnosis of HLB $(38,43)$. Later, detection systems were developed using electron microscopy (29), HLB-specific fluorescent substance (45), and enzyme-linked immunosorbent assay (ELISA) with monoclonal antibodies $(13,14)$. PCR based detection methods were developed based on sequences of the $16 \mathrm{~s}$ ribosomal DNA and other regions of the bacterial genome $(22,24$, $28,50)$. Sensitive detection methods for confirmation of symptoms developed include real-time quantitative PCR (qPCR) (30-32) and loop-mediated isothermal amplification (41).

There is no good source of genetic resistance to HLB in the genus Citrus or its relatives, and the disease cannot be controlled once the trees are infected $(4,10,18)$. Management of HLB is dependent on prevention and reduction of inoculum in the field, achieved through the use of disease-free planting material, control of psyllid population in the groves, and timely removal of infected trees $(4,10,18)$. Because of limitations in the early detection of the disease, epidemiological models of the spread of HLB are based on symptoms, and assume a linear relationship between infection and symptom expression. HLB symptoms develop in about $20 \%$ of grafted plants within 3 to 12 months of graft inoculation under greenhouse conditions $(46,55)$, but the same cannot be assumed 
for large trees under field situations. The latency period for the disease prior to symptom expression under field conditions is not clear, and information about the interval between psyllid inoculation of ' $\mathrm{Ca}$. L. asiaticus' in a field tree and the time when other psyllids can acquire the HLB bacteria from that tree is not available.

The bacteria have been detected in both vectors, T. erytreae and $D$. citri in haemolymph and salivary glands $(39,57)$. In addition, D. citri has been shown to retain the bacteria for a period of up to 12 weeks (23), which suggests that the bacteria may be replicating in the psyllid. A DNA-DNA hybridization technique was developed to detect ' $\mathrm{Ca}$. L. asiaticus' bacteria in psyllids: About $40 \%$ of the psyllids collected in the fall (September) from Malaysia and $1 \%$ of the psyllids collected in the winter (February) from India were found to be carrying ' $\mathrm{Ca}$. L. asiaticus' (6). A higher incidence of ' $\mathrm{Ca}$. L. asiaticus' in $\mathrm{D}$. citri psyllids in the fall was reported in later studies (52). In Florida, an increase in ' $C a$. L. asiaticus' titer has been noticed in plants in the fall $(26,27)$. These results suggest a higher titer of ' $\mathrm{Ca}$. L. asiaticus' in both plants and insects in the fall than in the winter.

In a study of psyllids feeding on sweet orange seedlings graftinoculated with ' $\mathrm{Ca}$. L. asiaticus', it was possible to detect ' $\mathrm{C} a$. L. asiaticus' in extractions of single psyllids and those containing up to 25 psyllids by conventional PCR targeting of a 226-bp fragment between the tufB and secE genes (23). 'Ca. L. asiaticus' was detectable from single nymphs of 3rd to 5th instar stages as well. Transovarial transmission of ' $\mathrm{Ca}$. L. asiaticus' was not detected in D. citri $(23,57)$, but there has been at least one report of its occurrence in T. erytreae (54).

Even though methods have been developed to detect ' $\mathrm{Ca}$. L. asiaticus' in psyllids $(5,6,23)$, there has not been any attempt to use psyllids for early detection of HLB ingress into an area or an orchard. The present study was undertaken to develop a real-time qPCR technology (30) for large scale detection psyllids for the presence of ' $\mathrm{Ca}$. L. asiaticus', and to test psyllids collected from a variety of venues in an effort to account for the rapid widespread distribution of HLB observed in Florida since its first report in 2005 .

\section{MATERIALS AND METHODS}

Collection of psyllids. Nymphs (mostly fourth and fifth instars) and adults of $D$. citri were collected from both visually healthy and symptomatic plants belonging to Citrus, Murraya, and related genera (Tables 1 and 2) from commercial groves, retail and commercial nurseries, residential sites, and discount garden centers in different counties in Florida from August 2005 until December 2006. Adults were collected using an aspirator, and the nymphs were collected using a small paint brush. Many of the samples tested were submitted as routine regulatory samples by the inspection personnel of the Florida Department of Agriculture and Consumer Services, Division of Plant Industry (DPI), Gainesville, FL. A limited number of samples from suction traps (20) set up in Immokalee (Collier County), Winter Haven (Polk County), Miami (Miami-Dade County), La Belle (Hendry County), and Loxahatchee (Palm Beach County) also were analyzed. The insects were catalogued and stored in $95 \%$ ethanol in $2 \mathrm{ml}$ tubes at the DPI, Gainesville, and shipped to the National Clonal Germplasm Repository, USDA-ARS, Riverside, California, for further analysis. At Riverside, the psyllids were assigned unique sample numbers with the prefix $\mathrm{F}$ and nymph samples with an additional suffix $\mathrm{n}$, and stored at $-20^{\circ} \mathrm{C}$ until processed. Healthy controls for both adults and nymphs were provided by R. Nguyen, DPI, Gainesville, Florida, from a colony maintained in cages, and by V. French, Texas A\&M University, Weslaco, TX, from a field collection.

DNA extraction from psyllids. DNA from single or multiple (up to 50) psyllid nymphs or adults was extracted according to De
Barro et al. (11). Briefly, the psyllids were air-dried for $10 \mathrm{~min}$, transferred to a $1.5-\mathrm{ml}$ microfuge tube containing $300 \mu \mathrm{l}$ of extraction buffer (10 mM Tris, $\mathrm{pH} 8.0,100 \mathrm{mM} \mathrm{NaCl}, 1 \mathrm{mM}$ EDTA, and 2\% SDS) and 20 units of Proteinase $\mathrm{K}$ (New England Biolabs), ground finely using a pellet pestle (Fisher Scientific Co.) connected to a cordless handheld motor. After incubating either at $50^{\circ} \mathrm{C}$ for $3 \mathrm{~h}$ or $37^{\circ} \mathrm{C}$ overnight, the nucleic acids were extracted using $300 \mu \mathrm{l}$ of phenol-chloroform-isoamyl alcohol (25:24:1), followed by a second extraction using $300 \mu \mathrm{l}$ of chloroform-isoamyl alcohol (24:1). The aqueous phase was ethanol precipitated and the resulting DNA pellet was dissolved in 20 to $50 \mu \mathrm{l}$ of sterile water and stored at $-20^{\circ} \mathrm{C}$.

Steps were taken to avoid any possibility of contamination between samples. Psyllid samples from Florida were extracted separately and not processed along with samples from other locations. All extractions and tests were carried out in a blind fashion once the extraction numbers were assigned to them. Each batch of psyllid extractions included at least one extraction with water as a negative control to monitor any cross contamination between the samples. When a psyllid sample was found to be positive for ' $\mathrm{Ca}$. L. asiaticus', DNA extractions were repeated using additional psyllids from the same sample, when available, and tested by qPCR. Selected samples were also tested by conventional PCR and/or sequenced for confirmation.

Conventional PCR and sequencing. Psyllid DNA extractions were used for conventional PCR amplification using 16s rDNA primers $\mathrm{OI} 1$ and $\mathrm{OI} 2 \mathrm{c}$ (28). The reaction mixture contained $20 \mathrm{mM}$ Tris-HCl, pH 8.8, $10 \mathrm{mM} \mathrm{KCl}, 10 \mathrm{mM}\left(\mathrm{NH}_{4}\right)_{2} \mathrm{SO}_{4}, 2 \mathrm{mM}$ $\mathrm{MgSO}_{4}, 0.1 \%$ Triton $\mathrm{X}-100,500 \mathrm{nM}$ of each of the primers, OI and OI $2 \mathrm{c}, 50 \mu \mathrm{M}$ dNTPs, $2 \mu \mathrm{l}$ of template DNA, and 1 unit of Taq DNA polymerase (New England Biolabs) in a reaction volume of $25 \mu \mathrm{l}$. The PCR products were cloned in pGEMT plasmid (Promega) using standard protocols and sequenced at the University of California Riverside, Institute of Integrative Genome Biology facility. Selected PCR products were sequenced directly without cloning, using two internal primers, CIT 220 (GCTCAACCTTGGAACTGC) and CIT 221 (CAGTATCAGGCCAGTGAG). The sequences were analyzed and compared using Contigexpress (Invitrogen), ClustalX (49), GenDoc (40), and Treeview (42) computer programs.

Design of Taqman probe and primers. Primers and TaqMan probe labeled with the fluorescent reporter dye 6-carboxyfluorescein (FAM) used for detection of Liberibacters have been described previously (30). An internal control for monitoring the quality of psyllid DNA extraction was included in the assay. Sequences of a nuclear gene, wingless $(\mathrm{wg})$ which codes for a diffusible secreted glycoprotein, were obtained from 26 psyllid species (48) from the GenBank database. An alignment of these sequences was used to design two primers (DCF and DCR) and a TaqMan probe (DCP) to specifically amplify and detect a 74-bp region of the $w g$ gene of $D$. citri (Fig. 1). The $5^{\prime}$ terminal nucleotide of the probe was labeled with hexachlorofluorescein (HEX) reporter dye and the $3^{\prime}$ nucleotide with Black Hole Quencher (BHQ-1). The primers were designed such that the annealing temperature of the $w g$ primers is close to that of the primer set used for detection of ' $C a$. L. asiaticus', and the two sets can be multiplexed. The primers and probes used in the study were synthesized by Integrated DNA Technologies, Inc.

Multiplex real-time qPCR. Real-time qPCR reactions were carried out using optical grade 0.2-ml 8-strip tubes and caps (Stratagene). The real-time PCR amplifications were performed using a Stratagene $\mathrm{Mx} 3005 \mathrm{P}$ thermocycler in 25- $\mu \mathrm{l}$ reactions containing $20 \mathrm{mM}$ Tris- $\mathrm{HCl}, \mathrm{pH} 8.8,10 \mathrm{mM} \mathrm{KCl}, 10 \mathrm{mM}$ $\left(\mathrm{NH}_{4}\right)_{2} \mathrm{SO}_{4}, 2 \mathrm{mM} \mathrm{MgSO}, 0.1 \%$ Triton $\mathrm{X}-100,250 \mu \mathrm{M}$ of dNTPs, $250 \mathrm{nM}$ each of primers HLBas, HLBr (30), DCF and DCR, $150 \mathrm{nM}$ each of probes HLBp (30), and DCP, and 2.5 units of Taq DNA polymerase (New England Biolabs). Water was added to bring the volume to $23 \mu \mathrm{l}$, and $2 \mu \mathrm{l}$ of template was used 
per reaction. Each PCR assay of 96 sample tubes contained the following controls: two tubes with water (no template control, NTC) as negative PCR controls, one tube with "no psyllid" extractions as extraction control, two tubes containing dilutions of plasmid DNA pLas (containing target DNA sequence from ' $\mathrm{Ca}$. L. asiaticus' in pGEMT plasmid), and one tube containing ' $\mathrm{Ca}$. L. asiaticus'-positive DNA extraction as positive controls. Since 8tube strips were used for PCRs, the plasmid controls were always located in the twelfth 8-tube strip to avoid any possible contamination of test samples in other tubes. The PCR cycling conditions were: $95^{\circ} \mathrm{C}$ for $5 \mathrm{~min}$ followed by 40 cycles of $95^{\circ} \mathrm{C}$ for $30 \mathrm{~s}$ and $58^{\circ} \mathrm{C}$ for $45 \mathrm{~s}$. The emissions were measured at each of the 40 extension steps. The cycle threshold $(\mathrm{Ct})$ value, which is the number of the PCR cycle at which the fluorescence increases above the threshold was determined automatically by the MxProMx3005P version 3.00 software (Stratagene). A pGEMT plasmid containing a cloned fragment of 16 s rDNA of ' $\mathrm{Ca}$. L. asiaticus' (pLas) was used for initial standardization of the real time PCR assay.

Preliminary optimization of concentrations of reagents including primers and probes was done using known positive and nega- tive DNA extractions, as well as dilutions from the plasmid pLas. A standard curve was prepared using dilution series from the plasmid pLas. The effect of addition of psyllid DNA-specific primers and probe on detection of ' $\mathrm{Ca}$. L. asiaticus' was studied using both cloned DNA template and psyllid DNA extractions. A

TABLE 2. Incidence of 'Candidatus Liberibacter asiaticus' in psyllid adults and nymph samples collected from different sources in Florida

\begin{tabular}{lccc}
\hline Host genus/source & Adults & Nymphs & Total \\
\hline Bergera & $2 / 6^{\mathrm{a}}$ & $0 / 3$ & $2 / 9$ \\
Citrofortunella & $2 / 4$ & $0 / 2$ & $2 / 6$ \\
Citrus & $42 / 625$ & $37 / 370$ & $79 / 995$ \\
Fortunella & $0 / 6$ & $0 / 3$ & $0 / 9$ \\
Murraya & $14 / 82$ & $2 / 43$ & $16 / 125$ \\
Poncirus & & $0 / 1$ & $0 / 1$ \\
Severinia & $0 / 1$ & $0 / 1$ & $0 / 2$ \\
Suction trap & $6 / 66$ & & $6 / 66$ \\
Triphasia & $0 / 1$ & & $0 / 1$ \\
Total & & & $105 / 1,214$ \\
\hline
\end{tabular}

a 'Ca. L. asiaticus' positive/total number tested.

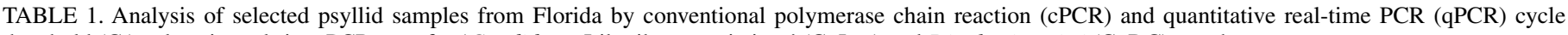
threshold $(\mathrm{Ct})$ values in real-time PCR tests for 'Candidatus Liberibacter asiaticus' (Ct Las) and Diaphorina citri (Ct DC) are shown

\begin{tabular}{|c|c|c|c|c|c|c|c|c|c|}
\hline ID $^{\mathrm{a}}$ & Date of collection & Host & Category $^{\mathrm{b}}$ & County & Psyllids/extraction ${ }^{\mathrm{c}}$ & Ct Las & $\mathrm{Ct}$ DC & $\mathrm{qPCR}^{\mathrm{d}}$ & cPCR \\
\hline F0001 & 8.10 .2005 & Murraya paniculata & Nursery & Miami-Dade & 3 & 32.13 & 27.14 & $\mathrm{~N}$ & $\mathrm{~N}$ \\
\hline F0003 & 8.10 .2005 & M. paniculata & Nursery & Miami-Dade & 6 & 0.00 & 24.36 & $\mathrm{~N}$ & $\mathrm{~N}$ \\
\hline F0003n & 8.10 .2005 & M. paniculata & Nursery & Miami-Dade & 10 & 35.70 & 24.98 & $\mathrm{~N}$ & $\mathrm{~N}$ \\
\hline F0004 & 9.29 .2005 & Citrus aurantifolia & Grove & Miami-Dade & 6 & 39.65 & 25.15 & $\mathrm{~N}$ & $\mathrm{~N}$ \\
\hline F0005 & 10.5 .2005 & C. aurantifolia & Residential & Palm Beach & 2 & 33.57 & 26.12 & $\mathrm{~N}$ & $\mathrm{~N}$ \\
\hline F0005n & 10.5 .2005 & C. aurantifolia & Residential & Palm Beach & 10 & 29.03 & 24.12 & $\mathrm{P}$ & W \\
\hline F0006 & 9.30 .2005 & C. limon & Residential & Broward & 5 & 37.15 & 24.90 & $\mathrm{~N}$ & $\mathrm{~N}$ \\
\hline F0007 & 9.30 .2005 & C. aurantium & Nursery & Miami-Dade & 4 & 0.00 & 25.75 & $\mathrm{~N}$ & $\mathrm{~N}$ \\
\hline F0007n & 9.29 .205 & C. aurantium & Nursery & Miami-Dade & 7 & 36.85 & 22.61 & $\mathrm{~N}$ & $\mathrm{~N}$ \\
\hline F0008 & 8.10 .2005 & M. paniculata & Nursery & Miami-Dade & 1 & 36.13 & 28.80 & $\mathrm{~N}$ & $\mathrm{~N}$ \\
\hline F0009 & 9.30 .2005 & C. sinensis & Residential & Broward & 2 & 35.12 & 27.24 & $\mathrm{~N}$ & $\mathrm{~N}$ \\
\hline F0010 & 10.1.2005 & Citrofortunella & small farm & Miami-Dade & 1 & 31.49 & 27.45 & $\mathrm{~N}$ & $\mathrm{~N}$ \\
\hline F0010n & 10.1.2005 & Citrofortunella & small farm & Miami-Dade & 5 & 34.52 & 27.33 & $\mathrm{~N}$ & $\mathrm{~N}$ \\
\hline F0011 & 10.5 .2005 & C. aurantium & Residential & Palm Beach & 3 & 24.56 & 31.80 & $\mathrm{P}$ & $\mathrm{P}$ \\
\hline F0012 & 10.7.2005 & M. paniculata & Nursery & Miami-Dade & 5 & 0.00 & 25.81 & $\mathrm{~N}$ & $\mathrm{~N}$ \\
\hline F0013 & 10.5 .2005 & M. paniculata & Nursery & Miami-Dade & 2 & 35.15 & 27.21 & $\mathrm{~N}$ & $\mathrm{~N}$ \\
\hline F0014 & 10.5 .2005 & Bergera koenigii & Nursery & Miami-Dade & 3 & 34.71 & 23.17 & $\mathrm{~N}$ & $\mathrm{~N}$ \\
\hline F0015 & 9.9.2005 & Suction trap & Suction trap & Polk & 1 & 25.66 & 31.60 & $\mathrm{P}$ & $\mathrm{P}$ \\
\hline F0016 & 9.15 .2005 & M. paniculata & Garden Center & Nassau & 2 & 24.75 & 25.56 & $\mathrm{P}$ & $\mathrm{P}$ \\
\hline F0017 & 9.19 .2005 & M. paniculata & Residential & Palm Beach & 2 & 24.27 & 30.84 & $\mathrm{P}$ & $\mathrm{P}$ \\
\hline F0018 & 9.22 .2005 & C. sinensis & Grove & Polk & 2 & 25.48 & 27.40 & $\mathrm{P}$ & $\mathrm{P}$ \\
\hline F0018n & 9.22 .2005 & C. sinensis & Grove & Polk & 5 & 18.75 & 29.94 & $\mathrm{P}$ & $\mathrm{P}$ \\
\hline F0019 & 9.22 .2005 & Citrofortunella & Grove & Polk & 1 & 24.26 & 28.91 & $\mathrm{P}$ & nd \\
\hline F0020 & 10.6.2005 & M. paniculata & Nursery & Miami-Dade & 3 & 27.39 & 25.60 & $\mathrm{P}$ & $\mathrm{P}$ \\
\hline F0020n & 10.6.2005 & M. paniculata & Nursery & Miami-Dade & 5 & 22.16 & 26.01 & $\mathrm{P}$ & $\mathrm{P}$ \\
\hline F0136 & 1.30 .2006 & C. sinensis & Grove & Collier & 50 & 23.20 & 29.50 & $\mathrm{P}$ & $\mathrm{P}$ \\
\hline F0216 & 2.13 .2006 & C. sinensis & Grove & De Soto & 50 & 24.30 & 26.17 & $\mathrm{P}$ & $\mathrm{P}$ \\
\hline F0489 & 6.2 .2006 & Citrus sp. & Nursery & Marion & 2 & 28.55 & 25.71 & $\mathrm{P}$ & nd \\
\hline F0492n & 6.1 .2006 & C. sinensis & Garden Center & Marion & 10 & 30.49 & 20.93 & $\mathrm{P}$ & nd \\
\hline F0533n & 6.8 .2006 & Citrus sp. & Grove & Marion & 5 & 29.70 & 24.71 & $\mathrm{P}$ & nd \\
\hline F0536 & 6.5 .2006 & C. sinensis & Garden Center & Marion & 5 & 27.65 & 22.23 & $\mathrm{P}$ & nd \\
\hline F0536n & 6.5 .2006 & C. sinensis & Garden Center & Marion & 10 & 25.86 & 23.24 & $\mathrm{P}$ & nd \\
\hline F0537 & 6.8 .2006 & C. sinensis & Grove & Marion & 5 & 26.71 & 23.74 & $\mathrm{P}$ & nd \\
\hline F0537n & 6.8 .2006 & C. sinensis & Grove & Marion & 11 & 27.05 & 23.21 & $\mathrm{P}$ & nd \\
\hline F0538n & 6.7 .2006 & Citrus sp. & Nursery & Marion & 1 & 27.34 & 28.65 & $\mathrm{P}$ & nd \\
\hline F0541 & 6.7 .2006 & Citrus sp. & Nursery & Marion & 5 & 25.50 & 23.51 & $\mathrm{P}$ & nd \\
\hline F0541n & 6.7 .2006 & Citrus sp. & Nursery & Marion & 4 & 29.36 & 28.01 & $\mathrm{P}$ & nd \\
\hline F0547 & 6.5 .2006 & Citrus sp. & Nursery & Marion & 4 & 28.42 & 23.74 & $\mathrm{P}$ & nd \\
\hline F0547n & 6.5 .2006 & Citrus sp. & Nursery & Marion & 10 & 27.62 & 22.83 & $\mathrm{P}$ & nd \\
\hline F0552 & 6.5 .2006 & Citrus sp. & Nursery & Marion & 5 & 24.46 & 22.34 & $\mathrm{P}$ & nd \\
\hline $\mathrm{F} 0552 \mathrm{n}$ & 6.5 .2006 & Citrus sp. & Nursery & Marion & 11 & 28.05 & 23.51 & $\mathrm{P}$ & nd \\
\hline
\end{tabular}

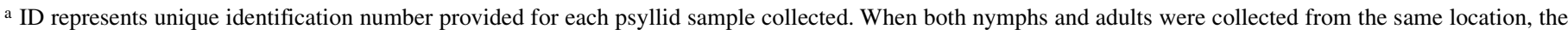
nymphs were given the same ID, but with suffix ' $n$ '.

b Category: includes several retail stores/nurseries with less than 500 plants per location.

c Psyllids/extraction: number of psyllid adults, or nymphs used per each DNA extraction.

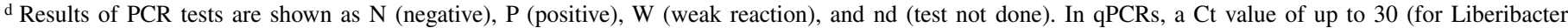
asiaticus) was regarded as positive, and those values above 30 and zeroes were regarded as negative. Conventional PCR analysis was based on visualization of expected size PCR products by agarose gel electrophoresis. 
dilution series of a ' $\mathrm{Ca}$. L. asiaticus'-positive psyllid DNA extraction was used to study the linearity of detection of both the ' $\mathrm{Ca}$. L. asiaticus' DNA and the psyllid DNA.

Data analysis. The cycle threshold $(\mathrm{Ct})$ values from each realtime PCR experiment were exported to an Excel data spreadsheet. The field data, DNA extraction details and conventional PCR information maintained on separate Excel data spreadsheets were then imported to Microsoft Access for database analyses.

\section{RESULTS}

Conventional PCR, cloning, and sequencing. A set of psyllid samples collected from different parts of Florida was used for the initial studies (F1 to F20; Table 1). DNA extractions were made using variable numbers of psyllids (1 to 10). Results from conventional PCR with primers OI1 and OI2c are shown in Table 1. The PCR products were cloned in a pGEM-T plasmid (Promega) for use as a control template in future experiments. Selected PCR products representing different counties were sequenced directly using internal primers CIT 220 and CIT 221. Representative sequences were submitted to GenBank (EU130552 to EU130556). The chromatograms were analyzed using the ContigExpress computer program (Invitrogen). Based on a very few conserved nucleotide differences in the $16 \mathrm{~s}$ rDNA of ' $\mathrm{Ca}$. L. asiaticus' from this study and those in the database, five different groups can be identified: Group A, represented by the majority of sequences in the database; group $\mathrm{B}$, with three sequences containing one nucleotide change at nucleotide 9 (DQ167273, DQ167274, and DQ167275; numbering based on DQ157275); group C, with two sequences containing two nucleotide changes at nucleotides 377 and 1,023 (DQ432004 and DQ431997); group D, with three sequences containing three changes at nucleotides 330, 353, and 972 (DQ43199, DQ432002, and DQ432005); and group E, with two sequences in this study containing no change/transversion from $\mathrm{T}$ to $\mathrm{Y}$ (a mix of $\mathrm{T}$ and $\mathrm{C}$ in the population) at nucleotide 333.

Standardization of singleplex and multiplex real-time qPCR. Preliminary standardization of real-time qPCR was done using known ' $\mathrm{Ca}$. L. asiaticus' positive and negative psyllid DNA extractions previously tested by conventional PCR of 16s rDNA (28), and the plasmid, pLas. The TaqMan assays were conducted using primer-probe set HLBas, HLBp, and HLBr (30), using a dilution series from the plasmid DNA pLas as templates for detection of ' $C a$. L. asiaticus'. The results demonstrated linearity in response to the DNA dilution series from the plasmid DNA template (Fig. $2 \mathrm{~A}$ and $\mathrm{B}$ ). The assays were repeated with the addition of two primers and a TaqMan probe designed for specific detection of psyllid DNA (Fig. 1); no appreciable difference in $\mathrm{Ct}$ values for detection of ' $\mathrm{Ca}$. L. asiaticus' (Fig. 2C) was observed. Similarly, the $\mathrm{Ct}$ values for detection of ' $\mathrm{Ca}$. L. asiaticus' with known healthy and ' $\mathrm{Ca}$. L. asiaticus' positive psyllid DNA extractions did not change when psyllid specific primers and probes were added in the PCR reaction mix (Fig. 2D). Dilution series were made from a DNA extraction from psyllids with ' $\mathrm{Ca}$. L. asiaticus' and tested by multiplex real-time qPCR using primers and TaqMan probes specific for ' $\mathrm{Ca}$. L. asiaticus' and the psyllid DNA. The results demonstrate linearity in response in both the ' $\mathrm{Ca}$. $\mathrm{L}$. asiaticus' assay and the psyllid DNA assay to the DNA dilution series (Fig. 3). Various PCR conditions, such as buffers, additives, concentrations of primers and probes, were standardized using both the plasmid DNA, pLas template, and known healthy and ' $C a$. L. asiaticus'-containing samples (data not shown). 'Ca. L. asiaticus'-free adults and nymphs were used as negative controls.

Detection of ' $\mathbf{C a}$. L. asiaticus' in psyllids. Initial testing of psyllid DNA samples by real-time qPCR was in agreement with the results from conventional PCR (Table 1). 'Ca. L. asiaticus' was detected from both adult and nymph samples. At least three replications per extraction were used for testing by real-time qPCR. The results shown in the Table 1 are mean values for the first two replications.

Over 1,200 psyllid samples collected from different hosts (Table 2) and locations (Table 3) were tested. A total of 105 samples were positive for ' $\mathrm{Ca}$. L. asiaticus'. Adult psyllids with 'Ca. L. asiaticus' were found from Citrus spp., Murraya paniculata, Bergera koenigii, and Citrofortunella microcarpa (Calamondin). However, nymphs infected with ' $\mathrm{Ca}$. L. asiaticus' were found only from Citrus spp. and M. paniculata.

Psyllids positive for ' $\mathrm{Ca}$. L. asiaticus' were found in samples collected from commercial groves, nurseries, retail stores, residences, and insect traps. While some of the ' $\mathrm{Ca}$. L. asiaticus'positive samples were collected from symptomatic trees and counties with records of plant infections, a large number of ' $\mathrm{Ca}$. L. asiaticus' positive samples came from unexpected sources, including asymptomatic trees, counties with no prior positive records for HLB, discount garden centers, small nurseries, and retail outlets. The records from the first collection of ' $\mathrm{Ca}$. L. asiaticus' positive samples from each county, from plants and psyllids, are shown in Table 3. While the results of psyllid analysis came from the present study, the information on ' $\mathrm{Ca}$. $\mathrm{L}$ asiaticus' analysis of plants was obtained from the DPI records. In six of thirteen counties, Brevard, Highlands, Marion, Nassau, Pasco, and Polk, positive psyllids were found prior to finding HLB positive plants in surveys.

' $\mathrm{Ca}$. $\mathrm{L}$. asiaticus' in adults versus nymphs. ' $\mathrm{Ca}$. L. asiaticus' was detected in both adults and nymphs of $D$. citri. Different combinations of results were obtained when the adults and nymphs collected from same source tree were analyzed. Out of 307 samples where both psyllid adults and nymphs were collected from the same source, both adults and nymphs were positive in 16 samples, only adults were positive in 8 samples, only nymphs were positive in 12 samples and both adults and nymphs were negative in 271 samples.

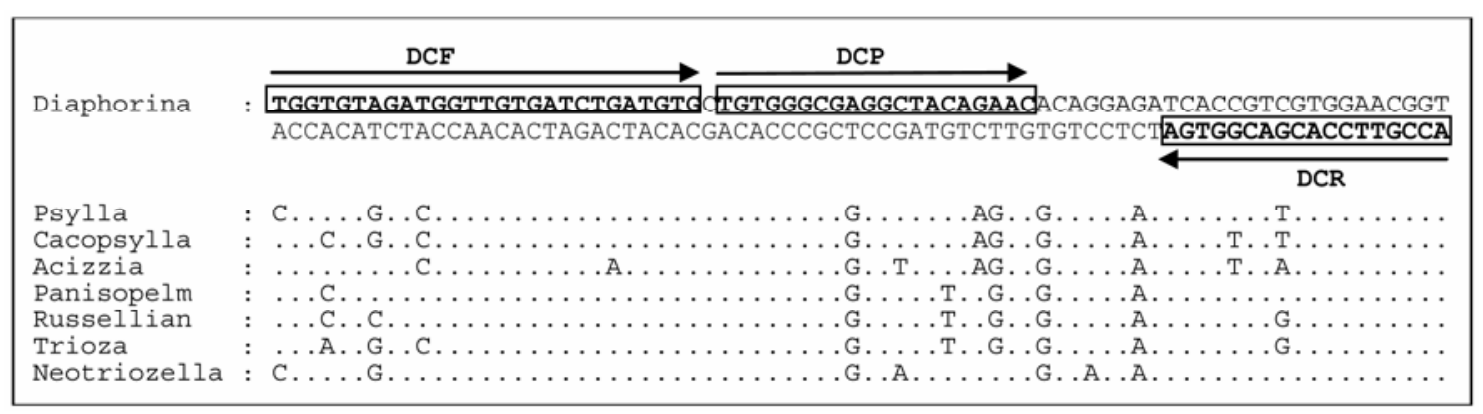

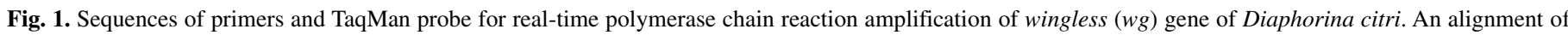

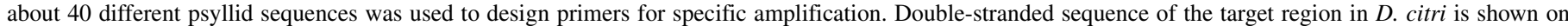

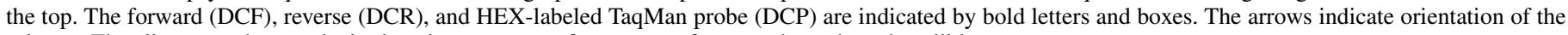
primers. The alignment shows substitutions in sequences of wg genes of seven other selected psyllid genera. 
' $\mathrm{Ca}$. L. asiaticus' in garden centers and retail nurseries. The psyllid samples were collected from 43 different counties in Florida, of which 700 samples were from small retail nurseries (including retail outlets such as tourist shops and small hardware stores) and discount garden centers. A few samples were collected from large commercial citrus nurseries, all of which tested negative for ' $\mathrm{Ca}$. L. asiaticus'. Sixteen out of 202 psyllid samples from discount garden centers, and 38 out of 502 samples from small nurseries and retail outlets were positive for ' $C a$. L. asiaticus' (Table 3). Amongst them, nine positive samples from garden centers and 12 positive samples from nurseries were nymphs, suggesting that the insect-source plants in the garden center were infected. In some cases, ' $C a$. L. asiaticus'-positive psyllids were detected in garden centers, retail stores, and nurseries well before HLB positive plants were found in commercial groves in the area (for example, Brevard, Marion, and Pasco counties).

Seasonality of ' $\mathrm{Ca}$. L. asiaticus' infection in psyllids. An analysis of the percent infection of ' $\mathrm{Ca}$. L. asiaticus' in both psyllid adult and nymph samples in different months was made (Fig. 4). The lowest levels of ' $\mathrm{Ca}$. L. asiaticus' infections were found in the cooler winter months while highest levels of infections were found in the September/October months, probably coinciding with feeding on fall flushes. A comparison of ' $\mathrm{Ca}$. L. asiaticus' incidence in psyllids in Florida (Fig. 4A and B) with the monthly psyllid population data (Fig. 4C) from a suction trap located in Loxahatchee (Palm Beach County) suggests that even though psyllid populations may reach a peak in April (spring flush), higher incidence of ' $C a$. L. asiaticus' may occur in September/October when populations are much lower.

\section{DISCUSSION}

Citrus production in Brazil and Florida is threatened by recent outbreaks of HLB. In each case, the discovery of HLB apparently came late, probably 5 to 10 years after the entry of the pathogen $(17,47)$, and the disease had become widespread prior to its discovery, exposing the lack of availability of effective monitoring techniques. Early disease detection and eradication of infected plants are critical for successful disease management. When HLB is found in a grove, the owner is faced with a difficult decision: either manage the disease through psyllid control and removal of infected trees, or eradicate the block. This decision would be easier if an indication of the extent of disease spread were known. Nursery trees and propagation source trees exposed to psyllids in an HLB-infected area must be considered as compromised, particularly since there is no reliable diagnostic method available to certify with certainty that they are disease-free. Success in citrus production will depend on internal grove management as well as reduction of external inoculum sources. The latter may include ' $\mathrm{Ca}$. L. asiaticus' infected plants in residential sites, abandoned groves, outdoor nurseries, or retail stores, and psyllids with ' $\mathrm{Ca}$. L. asiaticus' moving naturally and through planting materials. While the internal grove management is under the grower's control, the reduction of external sources of inoculum depends on effective regulation and public awareness.

The present study is an effort to develop a vector-based detection system to monitor pathogen movement for use as an additional tool for management of the disease. A real-time qPCR method had been recently developed for sensitive detection of
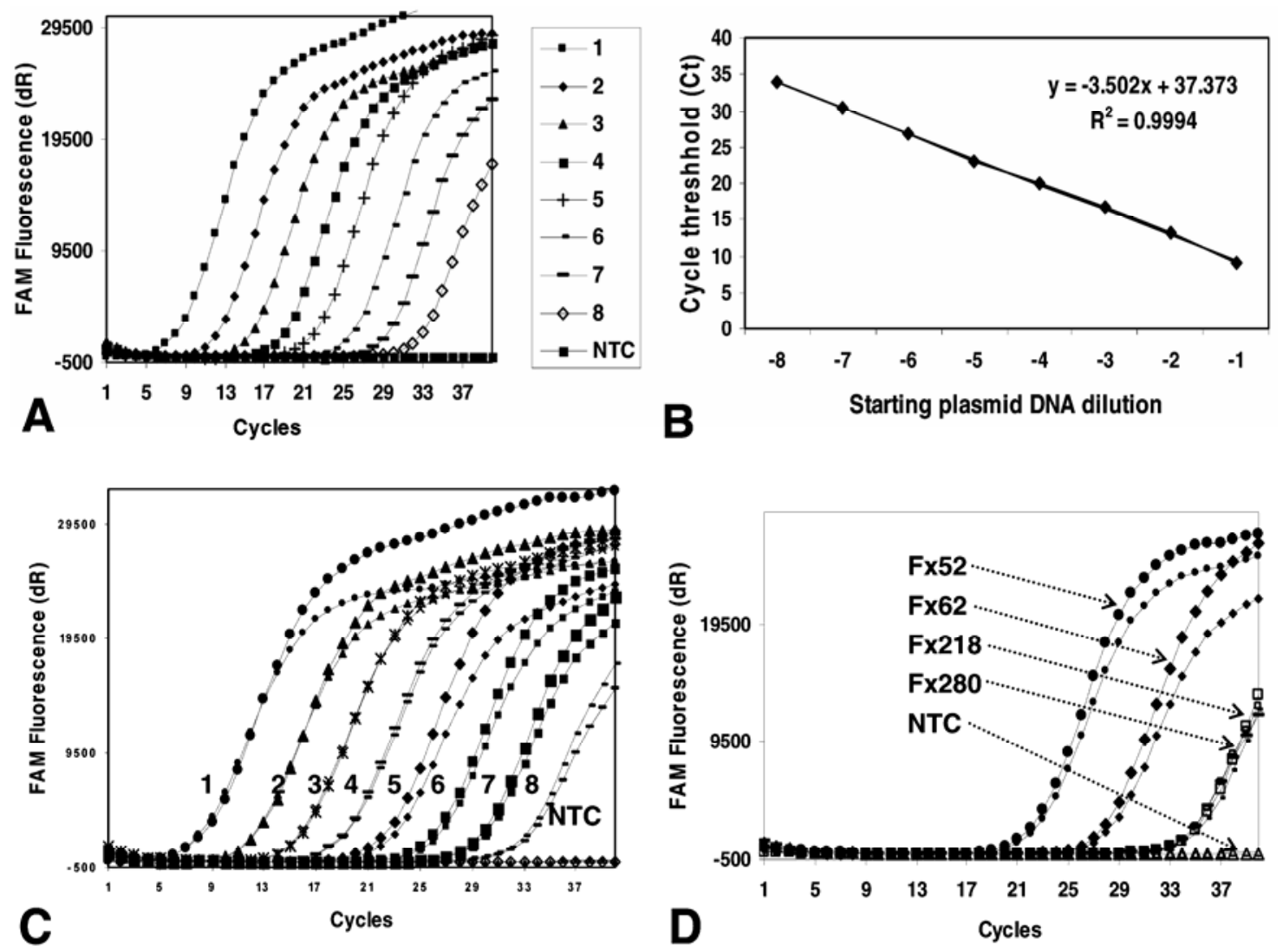

Fig. 2. A, Amplification profile from the real-time polymerase chain reaction of a dilution series of a plasmid DNA containing the target sequence, partial $16 \mathrm{~s}$ rDNA of 'Candidatus Liberibacter asiaticus'. B, Standard curve showing relationship between the starting DNA template and cycle threshold (Ct). C, Amplification profile for Las from the plasmid dilution series with or without the addition of primers and probe for detection of psyllid DNA. D, Amplification profile for Liberibacter asiaticus from four different psyllid DNA extractions with and without the presence of primers and probe for detection of psyllid DNA. Numbers 1 through 8 in $\mathbf{A}$ and $\mathbf{C}$ indicate serial dilutions of starting DNA template from $10^{-1}$ to $10^{-8}$, and NTC refers to no template control. The pairs of data series with small and corresponding large data point markers in $\mathbf{C}$ and $\mathbf{D}$ show fluorescence values in reactions with and without primers and probe for psyllid DNA, respectively. 
'Ca. L. asiaticus' from plants (30), and this methodology was adapted in the present study for the detection of ' $\mathrm{Ca}$. L. asiaticus' in psyllids. Selected samples positive for ' $\mathrm{Ca}$. L. asiaticus' in realtime PCR assays were further confirmed by analysis of additional psyllids (when available), conventional PCR of 16s rDNA and sequencing.

Detection of ' $\mathrm{Ca}$. L. asiaticus' in psyllids collected from asymptomatic plants. ' $\mathrm{Ca}$. L. asiaticus' was detected in psyllid samples collected from visually healthy trees in counties with no

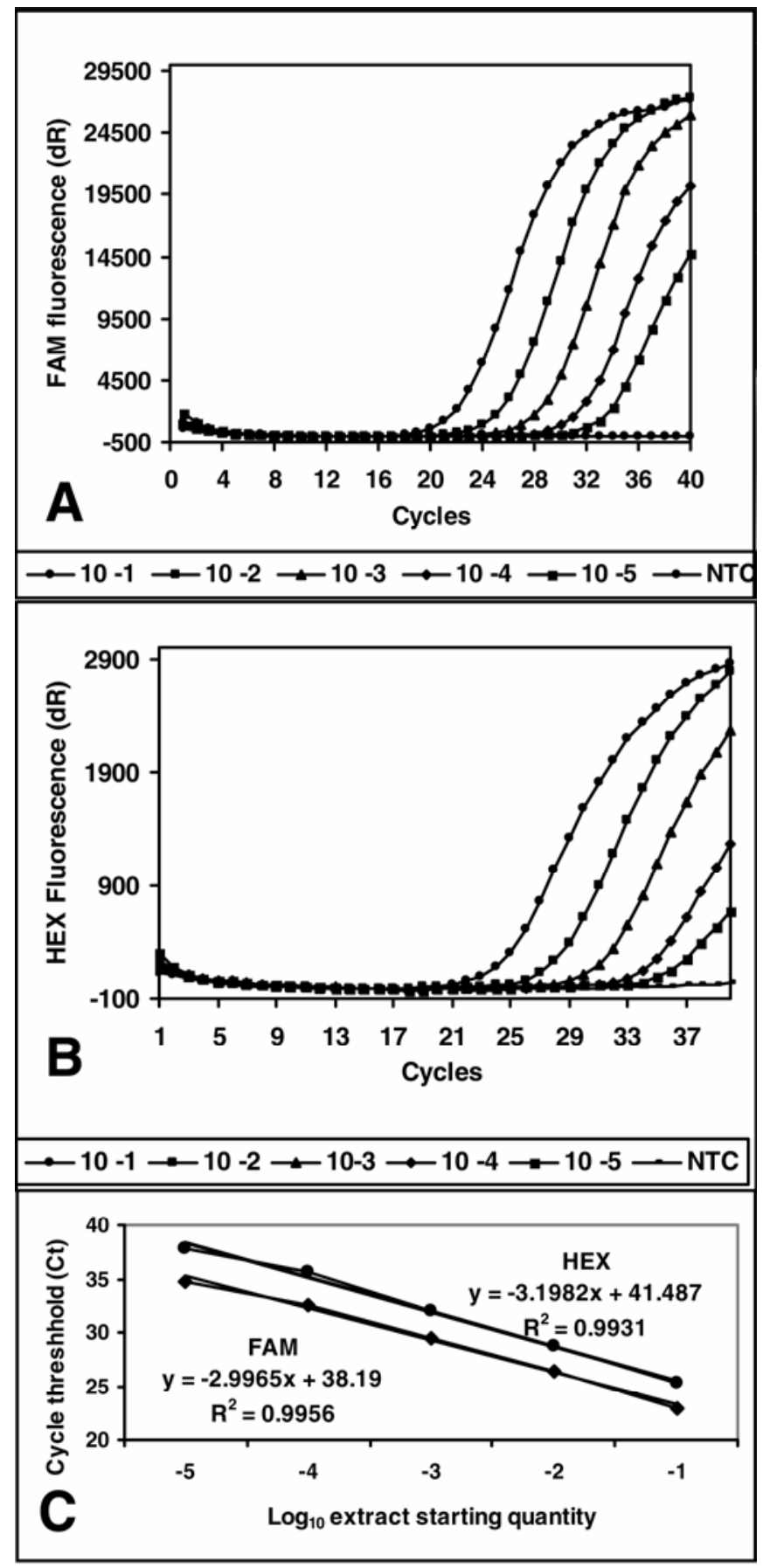

Fig. 3. A, Amplification profile from the real-time polymerase chain reaction (PCR) of a dilution series (data series starting from left, $10^{-1}$ to $10^{-5}$, and no template control, NTC) of a representative psyllid (Diaphorina citri) DNA extract (Fx 62) for the presence of 'Candidatus Liberibacter asiaticus'. B, Amplification profile from the real-time PCR of the same dilution series of the extract, Fx 62 using primers and probe for the psyllid DNA. C, Standard curves showing relationship between the starting DNA template concentration and cycle threshold $(\mathrm{Ct})$ for the bacterial DNA (FAM values) and the host psyllid DNA (HEX values). known plant records for HLB (at the time of psyllid sample collection), as well as from blocks or groves with no detectable HLB symptoms on plants. A psyllid sample (Table 1, F136) collected in January 2006 from a relatively isolated grove in Collier County with 3-year-old citrus was found to be positive for ' $C a$. L. asiaticus'. No HLB symptoms were observed on any of the plants in the block either at the time of collection or in followup visits in June and September 2006. A few trees with early HLB symptoms were found in November 2006, over 9 months after the detection of ' $C a$. L. asiaticus' in psyllids, and the presence of ' $C a$. L. asiaticus' in the symptomatic trees was then confirmed by PCR tests by the DPI. These observations and results suggest that the 3 -year-old trees in this block may have remained asymptomatic for more than 9 months.

In Polk County, 'Ca. L. asiaticus' positive psyllid samples (12 out of 135) were found from four different sites, including two groves, an abandoned nursery, and a suction trap starting September 2005. However, positive plants were not found in Polk County until August 2007. In those cases where ' $\mathrm{Ca}$. L. asiaticus' positive results were obtained from psyllids collected from visually healthy trees and those from counties with no plant infection records, further confirmation of the test results was done by conducting additional psyllid extractions from the same sample, when available, and by collecting and testing additional samples from the same site. For example, seven extractions were made from the sample F18n (nymphs), of which three were positive for ' $C a$. L. asiaticus' (data not shown). Adults from the same site (F18) were also positive. From another site, ' $\mathrm{Ca}$. L. asiaticus'positive psyllids were obtained in both hand collections made at different times and suction trap collections. Plants positive to ' $\mathrm{Ca}$. L. asiaticus' could not be detected at this site until August 2007 despite regular monitoring and testing.

In De Soto County, following finding of a ' $\mathrm{Ca}$. L. asiaticus' positive psyllid sample (Table 1, F216) from a grove in February 2006, two symptomatic plants were found at the same location during a follow-up inspection in July 2006. One of these trees was confirmed to be positive for HLB by DPI. Over 70 psyllid samples were collected from the same grove over a period of 1 year, and seven samples were found to be ' $\mathrm{Ca}$. L. asiaticus'positive (Table 3 ).

In Marion County, 13 out of 56 samples obtained from retail nurseries, garden centers, and grove sites, collected in June to August 2006, were 'Ca. L. asiaticus'-positive (Table 3). Adult and nymph samples collected from five different trees contained ' $\mathrm{Ca}$. L. asiaticus'. Additional extractions could be conducted from 8 of 13 'Ca. L. asiaticus'-positive samples, and seven of those repeat extractions tested positive for ' $\mathrm{Ca}$. L. asiaticus'. The first record of detection of ' $\mathrm{Ca}$. L. asiaticus' from a plant in the County was from an urban landscape tree in May 2007 (Table 3).

These results show that while a positive result from a psyllid analysis may be informative and useful for undertaking appropriate management decisions, negative results may not indicate absence of HLB activity in an area. Further, HLB movement in an area can be identified by psyllid analysis about one to several years prior to appearance of symptoms. The ideal time of psyllid sampling, sample size, and other parameters need to be determined. Assuming the lack of transovarial transmission $(23,57)$, psyllid nymphs, which do not move from plant to plant, may acquire ' $\mathrm{Ca}$. L. asiaticus' only from the tree on which they live. A nymph sample with ' $C a$. L. asiaticus' would indicate that the source plant is infected, while an adult with ' $\mathrm{Ca}$. L. asiaticus' may indicate only the presence of infected trees in the vicinity. Accordingly, plant source records are useful for analysis of the data obtained from nymph samples while the grove block records may be sufficient for the adult psyllid samples. Adult psyllid analysis from a grove may provide useful measure of HLB movement probably well before the disease can be detected in plants. 
Seasonality of ' $\mathrm{Ca}$. $\mathrm{L}$ asiaticus' incidence in psyllids. In this study, no attempt was made to collect psyllids from the same location for analyzing seasonality, if any, of the ' $\mathrm{Ca}$. L. asiaticus' infections in psyllids. However, it became apparent that the number of samples with ' $C a$. L. asiaticus' infections varied seasonally. Accordingly, the seasonal variations in ' $\mathrm{Ca}$. L. asiaticus' finds were analyzed (Fig. 4). Interestingly, the higher incidence of ' $\mathrm{Ca}$. L. asiaticus' did not correlate with higher population of psyllids. There is no information available on the effects of temperature or other environmental factors on acquisition, survival and multiplication of ' $C a$. L. asiaticus' in psyllids. The present analysis was based on results from a statewide collection with wide ranging differences in the environmental conditions. However, locally developed seasonality data may prove to be useful for management of HLB to determine appropriate strategies for psyllid control, timing of tree hedging, and other management practices.

' $\mathrm{Ca}$. L. asiaticus' in psyllids collected from retail stores. Several samples were collected from retail stores that market but do not propagate citrus trees, including garden stores, retail nurseries, and tourist shops. Both psyllid adult and nymph samples collected from these outlets have tested positive for ' $\mathrm{Ca}$. $L$. asiaticus'. The sources of ' $C a$. L. asiaticus' in psyllids usually are not easily traceable, but there are several possibilities. In the case of ' $\mathrm{Ca}$. L. asiaticus' positive adult psyllids, they could have come from the nursery that produced the plants. The psyllids could have acquired ' $\mathrm{Ca}$. L. asiaticus' from HLB positive citrus trees within the store or from infected trees around the business. Alternatively, the trees may have been raised from infected budwood, or the infections may have come from the liners (rootstocks), which may have been exposed to psyllids carrying ' $\mathrm{Ca}$. L. asiaticus'. There is also a remote possibility that ' $\mathrm{Ca}$. L. asiaticus' bacteria are transmitted transovarially. Earlier reports have shown no evidence of this process in D. citri (25), but there is at least one report that it may occur in T. erytreae (54). Regardless of the source, it is clear that HLB is being distributed in plants in retail stores. Psyllids appear to be thriving well in several retail stores, judging from the high number of insects collected from some venues. Temperature and other environmental conditions in garden stores, availability of continuous new flush for psyllid feeding, inadequate pesticide treatment, and lack of exposure to severe winter conditions may aid in better survival of both psyllids and ' $\mathrm{Ca}$. L. asiaticus' throughout the year in such an environment. Under these conditions, plants may be infected but asymptomatic, with a long latency period. These plants are moved to different counties as well as other states, and may serve as sources of inocula in new locations.

Millions of citrus trees are propagated and marketed in Florida annually. The fiscal year 2005/2006 inventory included 8,129,369 citrus plants for planting in commercial groves, 299,324 "own-use trees" for planting in commercial groves, and 1,259,302 trees propagated for residential planting (56). Psyllids were generally hard to find in large commercial nurseries, but appear to be very common in retail nurseries. The results presented in this study strongly suggest that movement of ' $\mathrm{Ca}$. L . asiaticus' infected plants and psyllids by retail stores may have played a significant role in rapid wide distribution of the disease, the effects of which are probably not yet fully realized and may become evident in the next few years as further disease progression takes place.

Florida nursery regulations about propagation and movement of citrus trees are changing (56). As of January 2007, all new citrus trees must be propagated in an approved enclosed structure. Nursery producers had until January 2008 to sell all previous stock, after which all citrus plants in propagating nurseries had to be enclosed. Nurseries and retail outlets are subject to frequent inspections for HLB symptoms in plants and freedom from psyllids, and propagation sources will be tested for ' $\mathrm{Ca}$. L. asiaticus' at least once a year. The new regulations should help prevent HLB and psyllid problems on citrus plants for sale in the future.

HLB and Murraya paniculata. Thirteen of the psyllid samples that were positive for ' $\mathrm{Ca}$. L. asiaticus' were collected from $M$. paniculata (orange jasmine) in retail outlets; twelve of these were from Miami-Dade County, where most Murraya plants are produced, and one sample was from Nassau County, the source of which was traced back to a Miami-Dade County nursery. The finding of a ' $\mathrm{Ca}$. L. asiaticus' positive psyllid in a Nassau County discount garden center demonstrates that ' $\mathrm{Ca}$. L. asiaticus'-positive psyllids can and do move with $M$. paniculata, a popular landscape ornamental plant. The state records for nursery stock do not list $M$. paniculata separately from other ornamental foliage plants, so it is impossible to know how many $M$. paniculata plants are sold in other counties and states annually. However, M. paniculata plants appear to be commonly sold in discount garden centers.

Liberibacters (both ' $\mathrm{Ca}$. L. americanus' and ' $\mathrm{Ca}$. L. asiaticus') were detected in $M$. paniculata trees in HLB-affected citrus areas

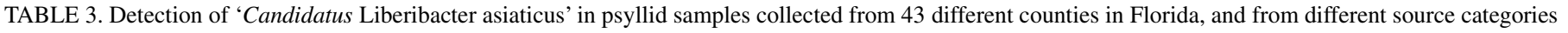

\begin{tabular}{|c|c|c|c|c|c|c|c|c|c|}
\hline County & Psyllid record ${ }^{\mathrm{a}}$ & Total & Garden center & Grove & Nursery & Residential & Business landscape & Suction trap & Plant record ${ }^{b}$ \\
\hline Alachua & & $0 / 26^{c}$ & $0 / 2$ & $0 / 9$ & $0 / 15$ & & & & \\
\hline Brevard & $5 / 31 / 06^{d}$ & $10 / 62$ & $2 / 25$ & $0 / 2$ & $8 / 35$ & & & & $12 / 7 / 06$ \\
\hline Broward & & $0 / 21$ & & $0 / 3$ & $0 / 13$ & $0 / 5$ & & & $9 / 14 / 05$ \\
\hline Collier & $1 / 30 / 06$ & $13 / 133$ & $0 / 8$ & $10 / 85$ & $1 / 5$ & $1 / 20$ & $0 / 4$ & $1 / 11$ & $11 / 29 / 05$ \\
\hline De Soto & $2 / 13 / 06$ & $7 / 75$ & $0 / 1$ & $7 / 74$ & & & & & $12 / 7 / 05$ \\
\hline Duval & & $0 / 69$ & $0 / 16$ & & $0 / 47$ & $0 / 4$ & $0 / 2$ & & \\
\hline Hendry & $1 / 28 / 06$ & $7 / 104$ & & $7 / 89$ & $0 / 5$ & $0 / 2$ & $0 / 2$ & $0 / 6$ & $10 / 11 / 05$ \\
\hline Highlands & $8 / 2 / 05^{d}$ & $2 / 12$ & $0 / 2$ & & $0 / 6$ & $2 / 4$ & & & $11 / 15 / 05$ \\
\hline Indian River & & $0 / 28$ & $0 / 7$ & $0 / 1$ & $0 / 18$ & $0 / 2$ & & & $7 / 12 / 07$ \\
\hline Marion & $6 / 2 / 06^{d}$ & $13 / 56$ & $2 / 12$ & $3 / 4$ & $8 / 38$ & $0 / 2$ & & & $5 / 17 / 07$ \\
\hline Miami-Dade & $10 / 08 / 05$ & $26 / 139$ & $5 / 13$ & $0 / 1$ & $19 / 104$ & $2 / 18$ & $0 / 1$ & $0 / 2$ & $8 / 23 / 05$ \\
\hline Monroe & $10 / 19 / 05$ & $2 / 8$ & & & $2 / 8$ & & & & $10 / 15 / 05$ \\
\hline Nassau & $9 / 15 / 05^{\mathrm{d}}$ & $1 / 14$ & $1 / 3$ & & $0 / 11$ & & & & \\
\hline Palm Beach & $10 / 5 / 05$ & $6 / 31$ & & $0 / 2$ & $0 / 3$ & $3 / 6$ & & $3 / 20$ & $9 / 28 / 05$ \\
\hline Pasco & $5 / 31 / 06^{d}$ & $3 / 34$ & $3 / 10$ & & $0 / 24$ & & & & $10 / 16 / 07$ \\
\hline Polk & $9 / 2 / 05^{d}$ & $12 / 135$ & $0 / 16$ & $10 / 47$ & $0 / 41$ & $0 / 3$ & $0 / 1$ & $2 / 27$ & 8/14/07 \\
\hline St. Lucie & $5 / 26 / 06$ & $3 / 31$ & $3 / 14$ & $0 / 7$ & $0 / 6$ & $0 / 4$ & & & $10 / 13 / 05$ \\
\hline Others & & $0 / 236$ & $0 / 73$ & $0 / 26$ & $0 / 123$ & $0 / 14$ & & & \\
\hline Total & & $105 / 1,214$ & $16 / 202$ & $37 / 350$ & $38 / 502$ & $8 / 84$ & $0 / 10$ & $6 / 66$ & \\
\hline
\end{tabular}

a The psyllid record indicates the earliest date of collection of a HLB-positive psyllid sample.

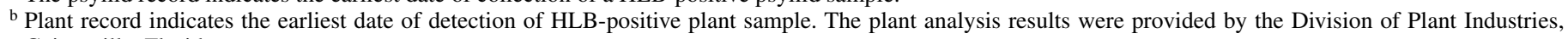
Gainesville, Florida.

c 'Ca. L. asiaticus'-positive/total number tested.

${ }^{\mathrm{d}}$ Indicates counties where HLB was detected in psyllids prior to its detection in plants. 
in Brazil (36). Analysis of over 350 samples of $M$. paniculata by PCR showed the presence of both ' $\mathrm{Ca}$. L. americanus' (10\%) and ' $C a$. L. asiaticus' $(0.6 \%)$, and the identity of the bacteria were further confirmed by graft transmissions from Murraya to Murraya and citrus to Murraya, but not from Murraya to citrus because of graft incompatibility (35). HLB has been transmitted to citrus from $M$. paniculata plants via dodder recently (58). In the present study, two of the psyllid nymph samples from $M$. paniculata were positive for ' $\mathrm{C} a$. L. asiaticus', indicating the probable presence of the bacterium in the host since nymphs do not move from plant to plant. This suggests that $M$. paniculata may be at least a transitory host of HLB bacteria in contrast to earlier reports $(25,58)$. Florida regulations now require that $M$. paniculata plants must be propagated under the same conditions as citrus.

Avenues for long-distance movement of HLB in Florida. Epidemiological studies on HLB under commercial production situations indicate that the disease progresses in a typical pattern of surrounding concentric circles $(2,15,16)$. Under these conditions, it takes several years for the grove to become totally infected. Similar situations appear to exist in Florida citrus groves where symptomatic trees are generally found very close to initial finds, typically within 20 to 50 tree spaces from the apparent center. These flight activity patterns are consistent with those of T. erytreae $(44,51,53)$. However, this local movement does not appear to account fully for the widespread distribution of HLB in Florida in a short span of 5 to 7 years.
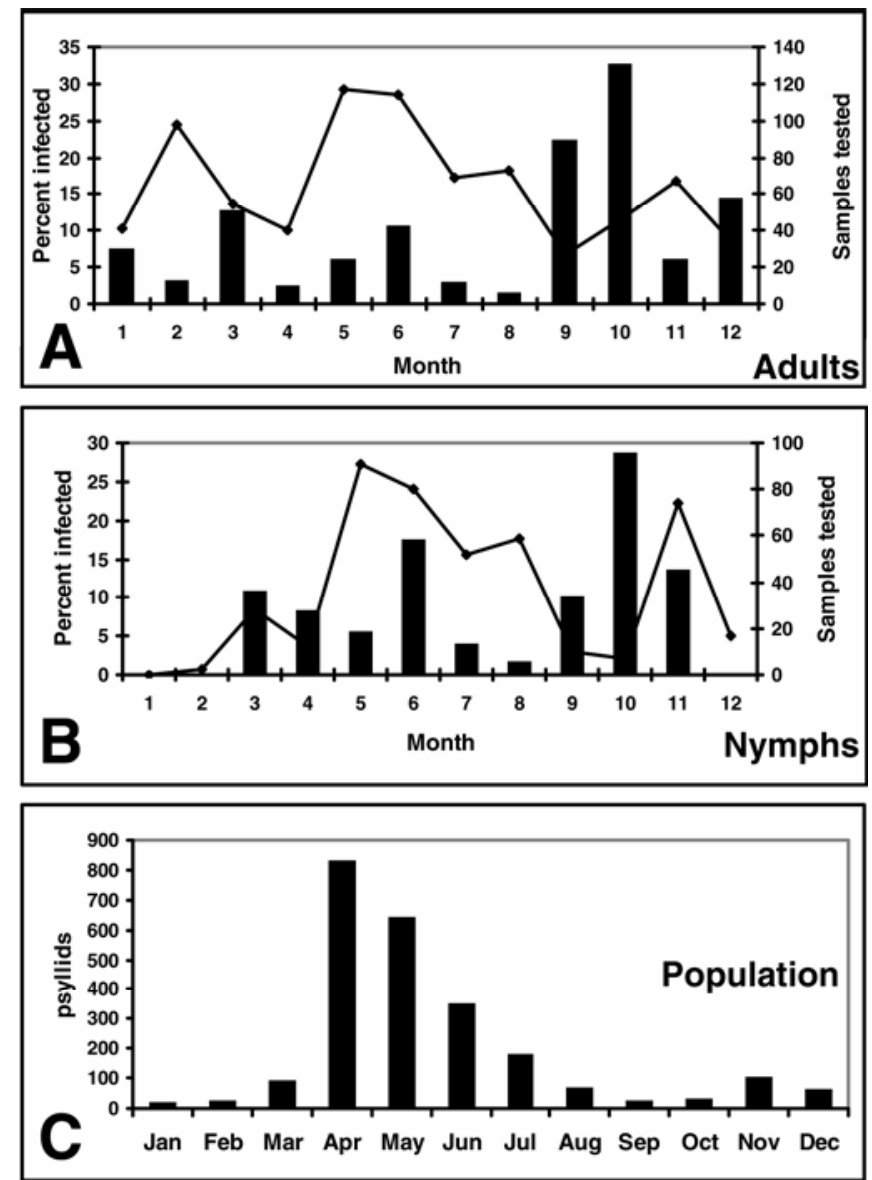

Fig. 4. Detection of 'Candidatus Liberibacter asiaticus' in A, psyllid adult and B, nymph samples collected from different parts of Florida in different months. Total number of samples tested each month (line graph) and percent samples with huanglongbing incidence (bar graph) are shown in each graph. Monthly data on the number of psyllids collected from a suction trap from March 2006 to February 2007, located in a citrus grove in Palm Beach is shown in graph $\mathbf{C}$.
D. citri was found for the first time in Florida in June 1998 (19). The psyllid did not become abundant in south central Florida until 2000 (S. E. Halbert, unpublished data). Extensive surveys in 1998 to 2000 in the southeast urban areas of Florida failed to detect HLB in any of the surveyed plants. Thus, HLB was probably spreading actively in Florida for a maximum of about 5 years prior to detection in 2005. At the time of writing this manuscript, HLB has been detected in plants in about 28 counties.

There is no documentation for D. citri flying long distances, but the potato psyllid, Bactericera cockerelli (Šulc) actually migrates transcontinentally every year (34). There is circumstantial evidence that infected $D$. citri flew across the Florida Everglades and infected the eastern borders of large commercial citrus groves just to the west of the Everglades (S. E. Halbert, unpublished data). Both the psyllids and ' $\mathrm{Ca}$. L. asiaticus' have been shown in this study to be moving with the plants for sale. Trade in $M$. paniculata plants almost undoubtedly has moved psyllid vectors carrying ' $\mathrm{Ca}$. L. asiaticus' (19) and facilitated the spread of HLB throughout Florida. It is now apparent that the means and pathways of movement of Asian citrus psyllid and citrus greening are diverse and common, and appear to have resulted in widespread distribution of HLB in the Florida peninsula and possibly to other states.

\section{ACKNOWLEDGMENTS}

This research was supported in part by T-STAR grant no. 2005-3413516526. We thank W. Dixon, DPI, Florida for providing facilities at the DPI for collection and maintenance of psyllid samples, and for permitting the use of plant-based test results for HLB, M. Brodie for organizing psyllid surveys, several inspectors including P. Carbon, L. Rigby, and J. Orr for collecting large number of psyllid samples, L. Stewart and S. Weingarten for providing psyllid samples, C. Campana for data entry, D. Ziesk for processing and shipping of samples, K. Ahlmark for processing suction trap samples, R. Nguyen and V. French for HLB-free psyllid samples, M. Anaya, C. Quevedo, and P. Ballance for technical help, and P. Metheney for assistance with setting up the database.

\section{LITERATURE CITED}

1. Anonymous. 2006. Citrus fruit: Fresh and processed, Annual statistics. Published online by Food and Agriculture Organization of the United Nations, Rome. http://www.fao.org/ES/ESC/common/ecg/28189_en_bull2006.pdf

2. Aubert, B. 1990. High density planting (HDP) of Jiaogan mandarin in the lowland area of Shantou (Guangdong, China) and implications for greening control. Pages 149-157 in: Rehabilitation of Citrus Industry in the Asia Pacific Region, Proc. Asia Pacific International Conference on Citriculture. B. Aubert, S. Tontyaporn, and D. Buangsuwon, eds. UNDPFAO, Rome.

3. Aubert, B. 1992. Citrus greening disease: A serious limiting factor for citriculture in Asia and Africa. Proc. Int. Soc. Citricul. 2:817-820.

4. Bove, J. M. 2006. Huanglongbing: A destructive, newly-emerging, century-old disease of citrus. J. Plant Pathol. 88:7-37.

5. Bove, J. M., Erti Dwiastuti, M., Triviratno, A., Suptiyanto, A., Nasli, E. and Becu, P. 2000. Incidence of huanglongbing and citrus rehabilitation in north Bali, Indonesia. Pages 378-380 in: Proc. 14th Conference of the International Organization of Citrus Virologists. J. V. da Graca, R. F. Lee, and R. K. Yokomi, eds. University of California. Riverside.

6. Bove, J. M., Garnier, M., Ahlawat, Y. S., Chakraborty, N. K., and Varma, A. 1993. Detection of the Asian strains of the greening BLO by DNADNA hybridization in Indian orchard trees and Malaysian Diaphorina citri psyllids. Pages 258-263 in: Proc. 12th Conference of the International Organization of Citrus Virologists. P. Moreno, J. V. da Graca, and L. W. Timmer, eds. University of California, Riverside.

7. Capoor, S. P., Rao, D. G., and Viswanath, S. M. 1967. Diaphorina citri Kuway., a vector of greening disease of citrus in India. Indian J. Agric. Sci. 37:572-576.

8. Coletta-Filho, H. D., Takita, M. A., Targon, M. L. P. N., and Machado, M. A. 2005. Analysis of $16 \mathrm{~S}$ rDNA sequences from citrus huanglongbing bacteria reveal a different "Ca. Liberibacter" strain associated with citrus disease in Sao Paulo. Plant Dis. 89:848.

9. Coronado-Blanco, J. M., and Ruiz-Cancino, E. 2004. Registro del "Psilido asiático de los citricos", Diaphorina citri Kuwayama (Homop- 
tera: Psyllidae) para México. Folia Entomol. Mex. 43:165-166.

10. da Graca, J. V., and Korsten, L. 2004. Citrus huanglongbing: Review, present status and future strategies. Pages 229-245 in: Diseases of Fruits and Vegetables. S. A. M. H. Naqui, ed. Kluwer Academic, The Netherlands.

11. De Barro, P. J., Sherratt, T. N., Brookes, C. P., David, O., and Maclean, N. 1995. Spatial and temporal variation in British field populations of the grain aphid Sitobion avenae (F.) (Hemiptera: Aphididae) studied using RAPD-PCR. Proc. R. Soc. Lon. Ser-B. 262:321-327.

12. French, J. V., Kahlke, C. J., and da Graca, J. V. 2001. First record of the Asian citrus psylla, Diaphorina citri Kuwayama (Homoptera: Psyllidae), in Texas. Subtropical Plant Sci. 53:14-15.

13. Gao, S. M., Garnier, M., and Bove, J. 1993. Production of monoclonal antibodies recognizing most Asian strains of the greening BLO by in vitro immunization with an antigenic protein purified from the BLO. Pages 244-249 in: Proc. 12th Conference of the International Organization of Citrus Virologists. P. Moreno, J. V. da Graca, and L. W. Timmer, eds. University of California, Riverside.

14. Garnier, M., Iskra, M. L., and Bove, J. M. 1987. Towards monoclonal antibodies against the apple proliferation mycoplasma-like organism. Israel J. Med. Sci. 23:691-695.

15. Gottwald, T. R., Aubert, B., and Huang, M. D. 1991. Spatial pattern analysis of citrus greening in Shantou, China. Pages 421-427 in: Proc. 11th Conference of the International Organization of Citrus Virologists. R. H. Brlansky, R. F. Lee, and L. W. Timmer, eds. University of California, Riverside.

16. Gottwald, T. R., Gonzales, C. I., and Mercado, B. G. 1991. Analysis of the distribution of citrus greening in groves in the Philippine. Pages 414420 in: Proc. 11th Conference of the International Organization of Citrus Virologists. R. H. Brlansky, R. F. Lee, and L. W. Timmer, eds. University of California, Riverside.

17. Halbert, S. E. 2005. The discovery of huanglongbing in Florida. Pages H3 in: Proc. of 2nd International Citrus Canker and Huanglongbing Research Workshop. Florida Citrus Mutual. Orlando, FL.

18. Halbert, S. E., and Manjunath, K. L. 2004. Asian citrus psyllids (Sternorrhyncha: Psyllidae) and greening disease of citrus: A literature review and assessment of risk in Florida. Fla. Entomol. 87:330.

19. Halbert, S. E., Niblett, C. L., Manjunath, K. L., and Lee, R. F. 2002. Establishment of two new vectors of citrus pathogens in Florida. Pages 1016-1017 in: Proc. International Soc. Citriculture IX Congress. ASHS Press, Alexandria, VA.

20. Halbert, S. E., and Nuessly, G. S. 2004. Species composition of Florida aphid fauna. Pages 147-150 in: Aphids in a New Millenium; Proc. 5th Int.Symp. on Aphids. J. C. Simon, C. A. Dedryver, C. Rispe, and M. Hulle, eds. INRA, Versailles.

21. Halbert, S. E., and Nunez, C. A. 2004. Distribution of the Asian citrus psyllid, Diaphorina citri Kuwayama (Rhynchota: Psyllidae) in the Caribbean Basin. Fla. Entomol. 87:401.

22. Hocquellet, A., Toorawa, P., Bove, J. M., and Garnier, M. 1999. Detection and identification of the two Candidatus Liberobacter species associated with citrus huanglongbing by PCR amplification of ribosomal protein genes of the beta operon. Mol. Cell. Probes 13:373-379.

23. Hung, T. H., Hung, S. C., Chen, C. N., Hsu, M. H., and Su, H. J. 2004. Detection by PCR of Candidatus Liberibacter asiaticus, the bacterium causing citrus huanglongbing in vector psyllids: Application to the study of vector-pathogen relationships. Plant Pathol. 53:96-102.

24. Hung, T. H., Wu, M. L., and Su, H. J. 1999. Development of a rapid method for the diagnosis of citrus greening disease using the polymerase chain reaction. J. Phytopathol. 147:599.

25. Hung, T. H., Wu, M. L., and Su, H. J. 2000. Identification of alternative hosts of the fastidious bacterium causing citrus greening disease. J. Phytopathol. 148:321-326.

26. Irey, M. S. 2006. Sensitivity of PCR-based methods for detection of Asiatic strain of the huanglongbing bacterium in symptomatic and asymptomatic citrus tissues (Abstr.). Pages 19 in: Proc. HuanglongbingGreening International Workshop. Riberao Preto, Brazil.

27. Irey, M. S., Gast, T., and Gottwald, T. R. 2006. Comparison of visual assessment and polymerase chain reaction assay testing to estimate the incidence of the Huanglongbing pathogen in commercial Florida citrus. Proc. Fla. St. Hortic. Soc. 119:89-93.

28. Jagoueix, S., Bove, J. M., and Garnier, M. 1996. PCR detection of the two 'Candidatus' Liberibacter species associated with greening disease of citrus. Mol. Cell. Probes 10:43-50.

29. Lafleche, D., and Bove, J. 1970. Mycoplasmes dans les argumes attentis de "greening", de stubborn, ou des maladies similaries. Fruits 25:455-465.

30. Li, W., Hartung, J. S., and Levy, L. 2006. Quantitative real-time PCR for detection and identification of Candidatus Liberibacter species associated with citrus huanglongbing. J. Microbiol. Methods 66:104-115.

31. Li, W., Hartung, J. S., and Levy, L. 2007. Evaluation of DNA amplification methods for improved detection of "Candidatus Liberibacter species" associated with citrus huanglongbing. Plant Dis. 91:51-58.

32. Liao, X. L., Zhu, S. F., Zhao, W. J., Luo, K., Qi, Y. X., Chen, H. Y., He, K., and Zhu, X. X. 2004. Cloning and sequencing of citrus huanglongbing pathogen 16s rDNA and its detection by real-time fluorescent PCR. J. Agric. Sci. 12:80-85.

33. Lima, A. C. 1942. Insetos do Brasil, Homopteros. Serie didatica 4 Escola Nacional de Agronomia 3:327.

34. Liu, D. G., Trumble, J. T., and Stouthamer, R. 2006. Genetic differentiation between eastern populations and recent introductions of potato psyllid (Bactericera cockerelli) into western North America. Entomol. Exp. Appl. 118:177-183.

35. Lopes, S. A. 2006. Huanglongbing in Brazil. Pages 11-19 in: Proceedings of the International Workshop for Prevention of Citrus Greening Disease in Severely Infested Areas. International Research Center for Agricultural Sciences. Ishigaki, Japan.

36. Lopes, S. A., Martins, E. C., and Frare, G. F. 2005. Detecção de Candidatus Liberibacter americanus em Murraya paniculata. Summa Phytopathol. 31:48-49.

37. McLean, A. P. D., and Oberholzer, P. C. J. 1965. Citrus psylla, a vector of the greening disease of sweet orange. S. Afr. J. Agric. Sci. 8:297-298.

38. Miyakawa, T. 1980. Experimentally-induced symptoms and host range of citrus likubin (greening disease). Ann. Phytopathol. Soc. Japan 46:224230.

39. Moll, J. N., and Martin, M. N. 1973. Electron microscope evidence that citrus psylla (Trioza erytreae) is a vector of greening disease in South Africa. Phytophylactica 5:41-44.

40. Nicholas, K. B., and Nicholas, H. B. 1997. GeneDoc: A tool for editing and annotating multiple sequence alignments. Published online by the National Resource for Biomedical Supercomputing (NRBSC), Pittsburgh, PA. www.psc.edu/biomed/genedoc.

41. Okuda, M., Matsumoto, M., Tanaka, Y., Subandiyah, S., and Iwanami, T. 2005. Characterization of the tufB-secE-nusG-rplKAJL-rpoB gene cluster of the citrus greening organism and detection by loop-mediated isothermal amplification. Plant Dis. 89:705.

42. Page, R. D. 1996. TreeView: An application to display phylogenetic trees on personal computers. Comput. Appl. Biosci. 12:357-358.

43. Roistacher, C. N. 1991. Greening. Pages 35-45 in: Techniques for Biological Detection of Specific Citrus Graft Transmissible Diseases. FAO, Rome.

44. Samways, M. J., and Manicom, B. Q. 1983. Immigration, frequency distributions and dispersion patterns of the psyllid Trioza erytreae (del Guercio) in a citrus orchard. J. Appl. Ecol. 20:463-472.

45. Schwarz, R. E. 1968. Indexing of greening and exocortis through fluorescent marker substances. Pages 118-124 in: Proc. 4th Conference of International Organization of Citrus Virologists. W. C. Price, ed. University of Florida, Gainesville.

46. Su, H. J., and Huang, M. D. 1990. The nature of likubin organism, life cycle, morphology and possible strains. Pages 106-110 in: Rehabilitation of Citrus Industry in the Asia Pacific Region. Proc. Asia Pacific International Conference on Citriculture. B. Aubert, S. Tontyaporn, and D., Buangsuwon, eds. UNDP, FAO, Rome. Chiang Mai, Thailand.

47. Teixeira, D. D. C., Danet, J. L., Eveillard, S., Martins, E. C., De Jesus, W. C., Jr., Yamamoto, P. T., Lopes, S. A., Bassanezi, R. B., Ayres, A. J., Saillard, C., and Bove, J. M. 2005. Citrus huanglongbing in Sao Paulo State, Brazil: PCR detection of the 'Candidatus' Liberibacter species associated with the disease. Mol. Cell. Probes 19:173.

48. Thao, M. L., Moran, N. C., Abbot, P., Brennan, E. B., Buckhardt, D. H., and Baumann, P. 2000. Cospeciation of Psyllids and their primary prokaryotic endosymbionts. Appl. Environ. Microbiol. 66:2998-2905.

49. Thompson, J. D., Gibson, T. J., Plewniak, F., Jeanmougin, F., and Higgins, D. G. 1997. The ClustalX windows interface: Flexible strategies for multiple sequence alignment aided by quality analysis tools. Nucleic Acids Res. 24:4876-4882.

50. Tian, Y., Ke, S., and Ke, C. 1996. Polymerase chain reaction for detection and quantitation of Liberibacter asiaticum, the bacterium associated with huanglongbing (greening) of citrus in China. Pages 252-257 in: Proc. 13th Conference of the International Organization of Citrus Virologists. J. V. da Graca, P. Moreno, and R. K. Yokomi, eds. University of California.

51. Tolley, S. 1990. The relation of nursery production with orchard planning and management. Pages 77-82 in: Rehabilitation of Citrus Industry in the Asia Pacific Region. Proc. Asia Pacific International Conference on Citriculture. B. Aubert, S. Tontyaporn, and D. Buangsuwon, eds. UNDPFAO, Rome.

52. Toorawa, P. 1998. La maladie du huanglongbing (greening) des agrumes a L'Île Maurice. Detection de "Candidatus Liberobacter asiaticum" et "Candidatus Liberobacter africanum" dans les agrumes et les insects vecteurs. L'University de Bordeaux.

53. van den Berg, M. A., and Deacon, V. E. 1988. Dispersal of the citrus psylla, Trioza erytreae (Hemiptera: Triozidae), in the absence of its host plants. Phytophylactica 20:361-368. 
54. van den Berg, M. A., van Vuuren, S. P., and Deacon, V. E. 1992. Studies on greening disease transmission by the citrus Psylla, Trioza erytreae (Hemiptera: Triozidae). Israel J. Entomol. 25-26:51-56.

55. Van Vuuren, S. P. 1993. Variable transmission of African greening to sweet orange. Pages 264-268 in: Proc. 12th Conference of the International Organization of Citrus Virologists. P. Moreno, J. V. da Graca, and L. W. Timmer, eds. University of California, Riverside.

56. Wester, R. S. 2006. Annual Report, Bureaux of Plant and Apiary Inspection, Florida Department of Agriculture and Consumer Services, Division of Plant Industry. Published online by Florida Administrative
Weekly \& Florida Administrative Code. https://www.flrules.org/ gateway/ChapterHome.asp?Chapter=5B-62.

57. Xu, C. F., Li, K. B., and Ke, C. 1988. Further study of the transmission of citrus huanglongbing by a psyllid, Diaphorina citri Kuwayama. Pages 243-248 in: Proc. 10th Conference of the International Organization of Citrus Virologists. L. W. Timmer, S. M. Garnsey, and L. Navarro, eds. University of California, Riverside.

58. Zhou, L. J., Gabriel, D. W., Duan, Y. P., Halbert, S. E., and Dixon, W. N. 2007. First report of dodder transmission of huanglongbing from naturally infected Murraya paniculata to citrus. Plant Dis. 91:227. 